\title{
Self-contained ventilation system of civil buildings built into window structures
}

\author{
Arman Kostuganov ${ }^{1, *}$, Yuri Vytchikov $^{1}$, and Andrey Prilepskiy ${ }^{1}$ \\ ${ }^{1}$ Samara State Technical University, Academy of Architecture and Civil Engineering, \\ Molodogvardeyskaya St., 194, Samara, 443001, Russia
}

\begin{abstract}
The article describes development and application of selfcontained ventilation systems in civil buildings. It suggests several models of air exchange within the building, compares these models and points out the variant of ventilating with self-contained mechanical systems with utilization of heat. The researchers conclude that structurally self-contained systems of mechanical ventilation with utilization of heat are most efficiently built into window constructions. This installation variant makes it possible to keep the interior, avoid building construction strengthening, shorten time and labor input of construction-assembling works, allow rational use of the vertical building envelopes area without extra space using. The paper key issue is the development of constructive solutions of self-contained ventilation systems main elements to ensure the possibility of their use in window structures. This research stage was developed with account of previous results of field tests and of such ventilation systems theoretical descriptions. The authors assess limit dimensions of the systems suitable for installment into window constructions of civil buildings in the view of modern Russian requirements to thermal protection. The research suggests a general constructive solution of such a ventilation system and a heat exchanger model which can be used as an air heat utilizer in these systems.
\end{abstract}

\section{Introduction}

The actual state of microclimate and the organization of a stable air exchange in civil buildings are of particular relevance today. That is confirmed by a significant number of works of modern researchers on this subject. Thus, for example, the state of the microclimate of premises and the questions of the normalization of its parameters are discussed in [1 - 3]. In works [4 - 9] the organization of the air mode of civil buildings to ensure the state of air comfort due to the operation of natural and mechanical ventilation systems are considered.

Today, the most common method of ventilation of civil buildings is the installation of a system of natural exhaust ventilation with an unorganized outside air inflow. Advantages of this method of air exchange is relatively low price and practical lack of operating costs. The main disadvantage of this method is its low efficiency (according to $[6,7]$ ).

\footnotetext{
* Corresponding author: kostuganovab@gmail.com
} 
A transitional option allowing to increase the efficiency of natural exhaust ventilation to some extent is combined or hybrid ventilation. Such a system, depending on the needs and the current situation, can operate in modes of natural or mechanical ventilation, though it is quite complex in installation, automation, operation and does not always allow heat utilization. Moreover, it should be noted that natural and hybrid ventilation can be effectively used only in multi-storeyed buildings, while for low-rise buildings these methods of organizing air exchange are practically not applicable.

The organization of mechanical ventilation is the most reliable and effective way of organizing air exchange, which allows to make full use of the energy saving potential of building and, first of all, due to the heat utilization of the ventilating air. Today, one of the most promising and least studied ways of organizing air exchange in civil buildings is the installation of autonomous (decentralized) ventilation systems for individual rooms. The shortcomings include relatively high cost of installation and operation of systems, additional sources of noise, some modifying of room interior. The advantages include the possibility of organizing a stable air exchange in a room and heat utilizing of the air. Particularly if we take into account that according to various estimates, heat loss with air exchange in modern buildings can reach $25 \%$ of the total heat loss [10], then the latter advantage becomes even more significant. Moreover, this method of organizing air exchange is applicable to all civil buildings and it doesn't depend on the number of storeys. In [11], the authors considered the effectiveness of the application of some self-contained ventilation systems based on the criteria for the magnitude of the air exchange created and the heat transfer efficiency determined as a result of full-scale tests.

The objectives of this study are:

1 Determination of the main overall dimensions of systems able to be placed into window structures;

2 Development of common fundamental solutions for self-contained ventilation systems built into window constructions of civil buildings;

3 Development of design solutions for some elements of self-contained ventilation systems.

\section{Materials and methods}

In the conclusions of the aforementioned paper [11], the authors note that such systems should meet a number of requirements. It is important that the system should occupy the smallest possible surface area of the room wall. In this regard, it is recommended to install it in the wall or under the window board, and under the window lintel. Today the existing systems of self-contained ventilation and heat recovery in the market of goods and services mainly involve the installation into a hole made in the thickness of building wall. Thus, this demands the following: modifying of the room interior and the external facades appearance of the building; work to strengthen the holes in the architectural building structures; the deadline increasing, complexity and intensity of the construction and installation works. If we consider the systems installation into the window design, it allows significantly to smooth out the listed shortcomings, as well as to rationally use the area of vertical enclosing structures without using an additional room capacity.

The primary task in the designing of construction options for the systems arrangement in the construction of a window board or a slope is the determination of necessary niches dimensions, which will determine the overall dimensions of the systems themselves. At the same time, the size of the niches depends on the thickness of the walls, which vary depending on the area of construction. However, these dimensions generally can be determined by the corresponding areas of construction. For example, in [12], we can find a reference to the map of Russia with the application of the corresponding required 
resistances to the heat transfer of the walls. Besides, if we take into consideration GOST 30971-2012, we can determine the main types of modern windows used in civil buildings.

The authors of this work carried out the analysis of the exterior walls thickness of modern structures in the main areas of construction and the analysis of the main types of modern windows. As the main variants of the modern construction walls were considered the following type: three-layer reinforced concrete panels, walls from small piece blocks, walls from porous ceramics, walls with a thin plaster layer ("wet facade"), walls with a hinged ventilated facade. As a result of the analysis, it was possible to determine the overall dimensions of self-contained ventilation systems in the respective areas of construction. Using in the subsequent stages of this study the generally accepted methods of research (system analysis of theoretical and experimental studies, analytical generalization of known scientific and practical results, the method of expert assessments, the use of general provisions of the theory of heat and mass transfer and aerodynamics), made it possible to develop several principal diagrams of self-contained ventilation systems with the utilization of heat. Based on the main provisions of the sources [13 - 20], the parameters of such basic elements of the systems as a fan, an air heater, a power unit were determined, as well as a heat exchanger - a heat utilizer for the ventilation air was designed.

\section{Results}

Analysis of modern Russian requirements for thermal protection of buildings showed that the maximum thicknesses of the main variants of modern construction walls vary in different areas of Russia in the range from 0.3 to $0.65 \mathrm{~m}$.

The information analysis of the GOST 30971-2012 allowed to establish that the main minimal size of the civil building window is $1 \mathrm{~m}$. As a result of the conducted research, it was generally possible to establish that the overall dimensions of the systems permitting their installation under the window board were: length $1000 \mathrm{~mm}$, width $400 \mathrm{~mm}$, height $300 \mathrm{~mm}$.

Figure 1 shows a schematic diagram of the developed systems of self-contained ventilation with the air heat utilization intended for installation into the windows construction.

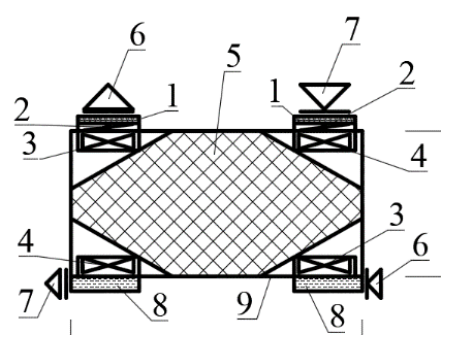

Fig. 1. Principal schematic diagram of the developed systems of self-contained ventilation. Notation: 1-filter; 2 - air damper; 3 - exhaust fan; 4 - supply air fan; 5 - heat exchanger - heat utilizer with freezing protection; 6 - exhaust air distributor; 7 - supply air distributor; 8 - sound absorber; 9 insulated body.

As a result of the subsequent development of the system design, it was possible to compile a list of the optimal system elements indicated in Figure 1: auxiliary fan, air heater, power unit, duct fittings. Figure 2 presents a model of the heat exchanger heat utilizer being developed for aerodynamic testing. Figure 3 shows the general view of the model being developed - the layout of the self-contained ventilation system. Figure 4 gives assembly view of the developed 3D model of the system. 


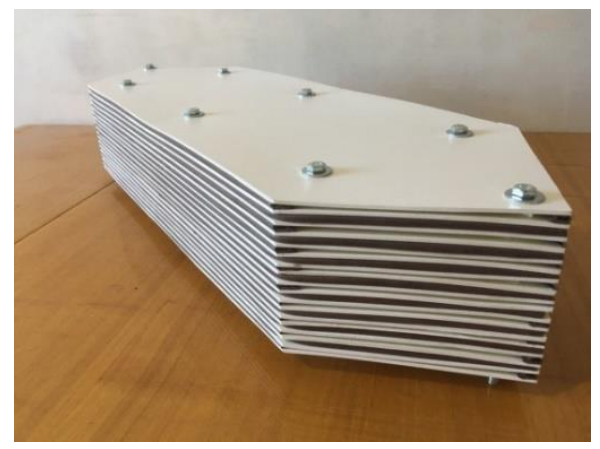

Fig. 2. Heat exchanger - heat utilizer model

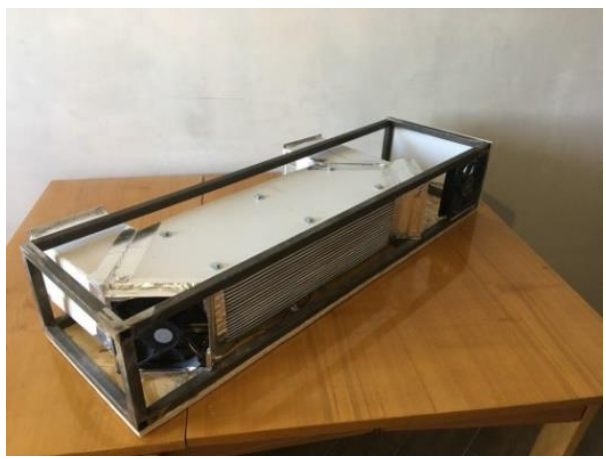

Fig. 3. Assembly view of model -self-contained ventilation system

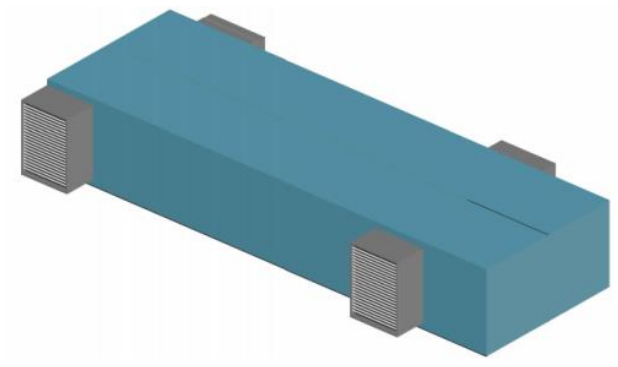

Fig. 4. 3D-system model

\section{Discussion}

For the developed list of system elements qualitative and quantitative selection criteria were formulated, on the basis of which, at the subsequent stages of system development, the basic elements will be finally selected. The description and values of the optimal selection criteria are given below in Table 1.

Table 1. Optimal selection criteria of system elements

\begin{tabular}{|l|l|l|l|}
\hline System element & Selection criteria & Criteria description & Value \\
\hline Main fan & Pressure & $\begin{array}{l}\text { The pressure developed } \\
\text { by the fan during the } \\
\text { system operation }\end{array}$ & $70 \ldots 200 \mathrm{~Pa}$ \\
\cline { 2 - 4 } & Air volume flow & $\begin{array}{l}\text { The fan's airflow during } \\
\text { the system operation }\end{array}$ & $30-60 \mathrm{~m}^{3} / \mathrm{h}$ \\
\hline
\end{tabular}




\begin{tabular}{|c|c|c|c|}
\hline System element & Selection criteria & Criteria description & Value \\
\hline \multirow[t]{2}{*}{ Auxiliary fan } & Pressure & $\begin{array}{l}\text { The pressure developed } \\
\text { by the fan during the } \\
\text { system operation }\end{array}$ & $20 \ldots 50 \mathrm{~Pa}$ \\
\hline & Air volume flow & $\begin{array}{l}\text { The fan's airflow during } \\
\text { the system operation }\end{array}$ & $30 \mathrm{~m}^{3} / \mathrm{h}$ \\
\hline Air heater & Thermal power & Heat transmitted to air & $0,2 \ldots 0,5 \mathrm{\kappa W}$ \\
\hline Filter & Degree of cleaning & Outside dust cleaning & $\begin{array}{l}\text { Rough air cleaning } \\
\text { from dust up to } 10 \\
\text { microns }\end{array}$ \\
\hline \multirow[t]{2}{*}{$\begin{array}{l}\text { Recuperative plate } \\
\text { heat exchanger - } \\
\text { heat utilizer }\end{array}$} & Material & $\begin{array}{l}\text { Providing high thermal } \\
\text { conductivity }\end{array}$ & $\begin{array}{l}\text { Steel (copper and } \\
\text { aluminum are } \\
\text { possible) }\end{array}$ \\
\hline & $\begin{array}{l}\text { Heat transfer } \\
\text { surface area }\end{array}$ & - & $1 \ldots 3 \mathrm{~m}^{2}$ \\
\hline Insulation & $\begin{array}{l}\text { Thermal insulation } \\
\text { of the system }\end{array}$ & Obstruction to heat loss & $\begin{array}{l}\text { brends: phenol and } \\
\text { penoplex }\end{array}$ \\
\hline Power unit & Voltage & $\begin{array}{l}\text { Voltage conversion } 220 \mathrm{~V} \\
\text { to } 12 \mathrm{~V} \text { or other required }\end{array}$ & $12 \mathrm{M}(5 \mathrm{~A}$ и $60 \mathrm{~W})$ \\
\hline Duct fittings & Connectors & $\begin{array}{l}\text { Connection of the } \\
\text { elements of the } \\
\text { ventilation systems to } \\
\text { each other }\end{array}$ & $\begin{array}{l}\text { The number and } \\
\text { dimensions are } \\
\text { determined by the } \\
\text { installation place in } \\
\text { the system }\end{array}$ \\
\hline Sound absorber & Noise reduction & $\begin{array}{l}\text { Installed noise absorbing } \\
\text { elements }\end{array}$ & $\begin{array}{l}\text { The maximum noise } \\
\text { level when operating } \\
\text { the system should not } \\
\text { exceed } 55 \mathrm{~dB} \text {. }\end{array}$ \\
\hline
\end{tabular}

\section{Conclusions}

Based on the results of the research, the following conclusions are formulated:

1. Overall dimensions of self-contained ventilation systems, according to the developed drawings and 3D-model, were: length $815 \mathrm{~mm}$., width $370 \mathrm{~mm}$., height $140 \mathrm{~mm}$. Taking into account the additional thickness of thermal insulation, we can state that the dimensions of the systems did not exceed the previously defined overall dimensions.

2. It is found that the optimum air velocity in the system is $1 \ldots 1.5 \mathrm{~m} / \mathrm{s}$ for an air flow rate of $30 \mathrm{~m}^{3} / \mathrm{h}$. This allowed us to form general aerodynamic schemes of the systems and, taking into account the previously defined overall dimensions of the systems, to select the necessary optimal elements of the aerodynamic circuits - fans and heat exchanger - heat utilizer. Heat exchanger - heat utilizer should be made of steel. Overall dimensions: length $640 \mathrm{~mm}$., width $200 \mathrm{~mm}$., height $120 \mathrm{~mm}$. The cross-sectional dimensions of all the other channels and elements of the system were selected on the basis of the provided average flow rate in the system $1 \ldots 1.5 \mathrm{~m} / \mathrm{s}$.

3. It is established that the surface area of the heat exchange for the heat utilization of the ventilation air should be at least $2 \mathrm{~m}^{2}$. For the heat exchanger- heat utilizer shown in figure 2 is $3 \mathrm{~m}^{2}$.

The authors are grateful to the Foundation for Promoting the Development of Small Forms Enterprises in the Scientific and Technical Sphere for their support and allocation of funding in the form of a grant for further research on the subject matter within the framework of the All-Russia Innovation Contest "U.M.N.I.K". 


\section{References}

1. Y.A. Tabunshchikov, AVOK 5, 1 (2008)

2. O. Fanger, AVOK 4, 2 (2003)

3. A.B. Kostuganov, B.M. Legkih, University complex as a regional center of education, science and culture 4, 787-794 (Orenburg State University, Orenburg, 2017)

4. A.B. Kostuganov, Y.S. Vytchikov, A.S. Prilepsky, Traditions and innovations in construction and architecture 5, 138-141 (Samara State University, Samara, 2017)

5. Y.S. Vytchikov, A.V. Sidorova, Traditions and innovations in construction and architecture 11, 284-286 (Samara State University of Architecture and Civil Engineering, Samara, 2013)

6. Y.S. Vytchikov, A.V. Sidorova, Urban Construction and Architecture 4, 15 (2013)

7. V.Y. Kuzin, Methods of year-round provision of air-thermal mode of multi-apartment houses (Polygraphic Center NNGASU, Nizhniy Novgorod, 2016)

8. M. B. Romeyko, D.V. Zelentsov, Traditions and innovations in construction and architecture 13, 783-784 (Samara State University of Architecture and Civil Engineering, Samara, 2014)

9. N.P. Tyurin, E.P. Lapin, G.I. Titov, Yu.E. Zakharova, Traditions and innovations in construction and architecture 11, 267-271 (Samara State University of Architecture and Civil Engineering, Samara, 2013)

10. V.G. Gagarin, V.V. Kozlov, Vestnik MGSU 7, 7 (2011)

11. A.B. Kostuganov, Y.S. Vytchikov, RSP 2017 - XXVI R-S-P seminar 2017 Theoretical foundation of civil engineering 117, 19 (EDP Sciences, Warsaw, 2017)

12. V.G. Gagarin, V.V. Kozlov, Vestnik MGSU 3, 30 (2011)

13. O.Y. Kokorin, Domestic equipment for the creation of ventilation and air conditioning systems (MGSU, Moscow, 2005)

14. V.M. Cays, A.L. London, Compact Heat Exchangers (Energia, Moscow, 1967)

15. A.M. Protasevich, Power supply in heat and gas supply, ventilation and air conditioning (Novoe Znanie, Minsk, 2012)

16. V.N. Bogoslovsky, M.Y. Pos, Thermophysics of heat recovery devices for heating, ventilation and air conditioning (Stroyizdat, Moscow, 1983)

17. S.A. Kolodyazhny, A.A., Kavyhin, Vestnik VolgGASU 36, 27 (2014)

18. A.O. Krektunov, Heat exchangers - utilizers with effective transfer surface for ventilation systems and air conditioning systems (Saint - Petersburg, 2005)

19. I.E. Idelchik, Reference book on hydraulic resistance (Mechanical Engineering, Moscow, 1992)

20. H. Hausen, Heat transfer in countercurrent, direct flow and cross current (Energoizdat, Moscow, 1981) 